\title{
Management of brain abscesses in children
}

\author{
Gheorghiță Jugulete ${ }^{1,2^{*}}$, Monica Luminos ${ }^{1,2}$, Anca Drăgănescu', Magdalena Vasile', Angelica Vişan ${ }^{1,2}$,

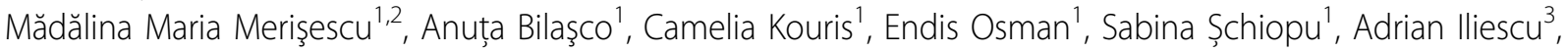 \\ Virgil lonescu ${ }^{4}$ \\ From The 9th Edition of the Scientific Days of the National Institute for Infectious Diseases Prof Dr Matei \\ Bals
}

Bucharest, Romania. 23-25 October 2013

\section{Background}

Bacterial brain abscess is an important cause of morbidity and mortality both in adults and in children. Usually, abscesses are secondary to congenital malformations or are complications of improperly treated infections. Rarely, abscesses appear without an apparent predisposing cause in a good state of health.

\section{Methods}

We performed a retrospective study on cases of bacterial brain abscesses admitted in the Pediatric Intensive Care Unit of the National Institute for Infectious Diseases "Prof. Dr. Matei Balş" between 01 January 2008 and 01 January 2013. We monitored age, gender, predisposing factors, comorbidities, onset, treatment, evolution and complications.

\section{Results}

In the aforementioned period we registered 12 cases of bacterial brain abscesses in children.

The female gender and the 8 to 14 age group have prevailed. $50 \%$ of cases presented a congenital heart defect, $25 \%$ untreated bacterial infections, $12.5 \%$ a history of craniocerebral injury and $12.5 \%$ presented no evident predisposing cause.

The onset consisted of: fever, vomiting, nausea, seizures, neurological problems. All of the cases required emergency neurosurgical treatment and specific antibiotherapy. Before the etiology of the infection was established, patients received empiric broad spectrum antibiotherapy (meropenem and linezolid), with subsequent antibiotic de-escalation over the next 6 weeks.
The treatment was monitored clinically, biologically and with imaging studies. The evolution was favorable in all cases. No deaths were registered. Neurological sequelae were present in $41.7 \%$ of the cases: hemiparesis, sight and speech problems, psycho-motor impairment, seizures.

\section{Conclusion}

Careful monitoring of predisposing factors of brain abscesses is important for this severe condition which can result in permanent sequelae or death.

\section{Authors' details}

${ }^{1}$ National Institute for Infectious Diseases "Prof. Dr. Matei Balş", Bucharest, Romania. ${ }^{2}$ Carol Davila University of Medicine and Pharmacy, Bucharest, Romania. ${ }^{3}$ Clinical and Emergency Hospital "Prof. Dr. Bagdasar Arseni", Bucharest, Romania. ${ }^{4}$ Provita - Center of Diagnosis and Treatment Bucharest, Romania.

Published: 16 December 2013

doi:10.1186/1471-2334-13-S1-P98

Cite this article as: Jugulete et al.: Management of brain abscesses in children. BMC Infectious Diseases 2013 13(Suppl 1):P98.

\footnotetext{
* Correspondence: georgejugulete@yahoo.com

'National Institute for Infectious Diseases "Prof. Dr. Matei Balş", Bucharest,

Romania

Full list of author information is available at the end of the article
}

\section{Ciomed Central}

(c) 2013 Jugulete et al; licensee BioMed Central Ltd. This is an Open Access article distributed under the terms of the Creative Commons Attribution License (http://creativecommons.org/licenses/by/2.0), which permits unrestricted use, distribution, and reproduction in any medium, provided the original work is properly cited. 